でのところ何の回答も得られていない.

3) 取扱説明書の安全性記載関係

MR装置の取扱説明書に記載する资全性に関す る事項は，これまで各社まちまちであったが， IECの規格を基にして，必要な事項は必ず記載す るように団体規格化を進めてきた。

審議はほぼ終わり，まもなく団体規格として発 行される予定.

4) MRの性能評価法関係

NEMAやAAPMなどの㗢告を基にファントム を用いたMRの性能評価法を団体規格化しようと している。評価内容は, $\mathrm{S} / \mathrm{N}$ 比, 均一性, 歪み, スライス厚，分解能などとする.

現在審議の方向か決められただけで実質的な審 議はまだ行われていない。次年度に持ち越され る。

5) CRT診断推進委貣会関係

フィルムレス診断が進行している中，厚生省は 使用されるCRT装置の性能基準について各方面 に意見を求めており，当委員会にも連絡があっ た。

主査が会議に出席し，MR関係の意見を反映さ せている。

6) 磁気共鳴医学会関係

磁気共鳴医学会, 放射線技術学会, 放射線機器 工業会の合同で作った，MRの安全性に関する $\lceil\mathrm{IEC}$ 規格対応委員会」は昨年度で解散したが，国 内ガイドラインやIEC WG28などでの関係は続い て抢り, 磁気共鳴医学会の安全評価委員会(亀井 委員長)に当委員会から委員を派遣し連絡を保っ ている.

（山田和美）

\section{5-6 放射線治療装置班}

1）医用電子加速装置の性能に関するIEC替格のJIS 化準備作業

過去数年にわたり審議を続けてきたIEC規格で あるIEC 60976, Medical electrical equipment. Medical electron accelerators-Functional performance characteristics. (医用電子加速装置一機能的 動作特性)の翻訳，JIS化に向けての最終作業を完 了し，審議終了した。

またここ規格に連携している規格である IEC60977, Medical electrical equipment. Medical electron accelerators in the range $1 \mathrm{MeV}$ to $50 \mathrm{MeV}$ Guidelines for functional performance characteristics. (機能的動作特性の指標)の日本語化とデイ ジタル化作業を完了した。
現在，IEC60976は次年度においてJIRAが原案 作成団体としてJIS化の申請をすることが沠定し た。連携を保たなければならないIEC60977につ いても，同時進行が許可されるように交渉をして いる。

2) IEC医用電子加速装置関連規格の改定作業 世界的に普及が進んでいるマルチリーフコリメ 一夕の機能特性およびその指標を，前述の規格に 組み入れるべく，IECは改訂作業に入った $(62 \mathrm{C} /$ 247/CDV抢よび62C/248/CDV)。本班での審議も 終了し，日本語化も終えている。内容に問題はな く，国内取入れについては，新規格である IEC60976と60977のJIS化の進行とのタイミング を図る段階にある。

3) シミェレータ関係

IEC 62C/213/CDV, 60601-2-29, Ed.2,: Part 2, Particular requirements for the safety of radiotherapy simulators.に対する番議を行った。日本側とし て, 内容的にコメントする点はなく承認すること に決定した。

4) 用語の改訂関係

IEC 60788, Medical radiology terminologyの 改訂に関連し，放射線治療関連の用語の採否につ いて検討を行った。

（保科正夫）

\section{5-7 線量計班}

1997年 9 月から行われていたIEC60580: Dose area product meters (面積線量計)の改訂作業は, 間もなく 終了する。

IEC61674: Medical electrical equipment-dosimeters with ionization chambers and/or semiconductor detec-

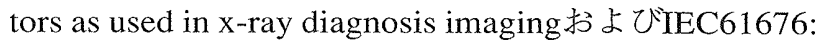
Medical electrical equipment-dosimetric instruments for non-invasive measurement of $x$-ray tube voltage in diagnostic radiologyに関する検討が現在進行している。

(津由政行)

\section{5-8 X線防護班}

IECより送付された，IEC62B/347/FDIS番議資料 (IEC 61331-3,Ed.1: Protective devices against diagnostic medical x-radiation-Part 3: Protective clothing and protective devices for gonads)について, IEC62B/316/CDV との比較および改正点について，審議した。 〈改正点〉

(1)防護スカートの規格が削除された.

(理由)ベストなしのスカート着用は，钬めら れない. 防護エプロンの注にスカートとベス 